\title{
Metabolic effects of the contraceptive skin patch and subdermal contraceptive implant in Mexican women: A prospective study
}

Jesus Hernandez-Juarez ${ }^{1,2}$, Ethel A Garcia-Latorre², Manuel Moreno-Hernandez ${ }^{1}$, Jose Fernando Moran-Perez ${ }^{3}$, Miguel Angel Rodriguez-Escobedo ${ }^{3}$, Gerardo Cogque-Hernandez ${ }^{4}$, Rubén Julián-Nacer ${ }^{4}$, Xochitl Hernandez-Giron ${ }^{5}$, Rosalia Palafox-Gomez ${ }^{4}$, Irma Isordia-Salas ${ }^{1}$ and Abraham Majluf-Cruz ${ }^{1 *}$

\begin{abstract}
Background: The contraceptive skin patch (CSP) accepted by the U.S. FDA in 2001 includes ethinylestradiol and norelgestromine, whereas the subdermal contraceptive implant (SCI) has etonogestrel and is also approved by the FDA. In Mexico, both are now widely used for contraception but their effects on Mexican population are unknown. The objective of the study was to evaluate if these treatments induce metabolic changes in a sample of indigenous and mestizo Mexican women.
\end{abstract}

Methods: An observational, prospective, longitudinal, non-randomized study of women between 18 and 35 years of age assigned to CSP or SCI. We performed several laboratory tests: clinical chemistry, lipid profile, and liver and thyroid function tests. Also, serum levels of insulin, C-peptide, IGF-1, leptin, adiponectin, and C reactive protein were assayed.

Results: Sixty-two women were enrolled, 25 used CSP (0 indigenous; 25 mestizos) and 37 used SCI (18 indigenous; 19 mestizos). Clinical symptoms were relatively more frequent in the $\mathrm{SCl}$ group. Thirty-four contraceptive users gained weight without other clinical significant changes. After 4 months of treatment, significant changes were found in some biochemical parameters in both treatment groups. Most were clinically irrelevant. Interestingly, the percentage of users with an abnormal atherogenic index diminished from $75 \%$ to $41.6 \%$ after follow-up.

Conclusions: The CSP slightly modified the metabolic variables. Most changes were nonsignificant, whereas for SCI users changes were more evident and perhaps beneficial. Results of this attempt to evaluate the effects of contraceptives in mestizo and native-American populations show that clinical symptoms are frequent in Mexican users of CSP and SCl. Although these medications may affect some metabolic variables, these changes seem clinically irrelevant. Induction of abnormalities in other physiological pathways cannot be ruled out.

Keywords: Contraceptive skin patch, Subdermal contraceptive implant, Metabolic effects, Metabolic changes, Contraception

\footnotetext{
* Correspondence: amajlufc@gmail.com

${ }^{1}$ Unidad de Investigacion Medica en Trombosis Hemostasia y Aterogenesis,

Instituto Mexicano del Seguro Social, Mexico City, Mexico

Full list of author information is available at the end of the article
} 


\section{Résumé}

Introducción: El parche cutáneo anticonceptivo (PCA), aceptado por la FDA en 2001, contiene etinilestradiol y norelgestromina mientras que el implante contraceptivo subdérmico (ICS) tiene etonogestrel y también fue aprobado por la FDA. En México, ambos son ahora ampliamente utilizados para la contracepción pero sus efectos sobre la población mexicana se desconocen. El objetivo de este estudio fue evaluar si estos tratamientos inducen cambios metabólicos en una muestra de mujeres mexicanas, indígenas y mestizas.

Métodos: Estudio observacional, prospectivo, longitudinal, no aleatorizado de mujeres entre 18 y 35 años de edad asignadas a PCA o a ICS. Realizamos varias pruebas de laboratorio: química clínica, perfil de lípidos y pruebas de funcionamiento hepático y tiroideo. También medimos las concentraciones de insulina, péptido C, IGF-1, leptina, adiponectina y proteína C reactiva.

Resultados: Sesenta y dos mujeres fueron estudiadas, 25 usuarias de PCA (0 indígenas y 25 mestizas) y 37 de ICS (18 indígenas y 19 mestizas). Los síntomas clínicos fueron relativamente más frecuentes en el grupo con ICS. Treinta y cuatro usuarias ganaron peso sin otros síntomas clínicos significativos. Después de 4 meses de tratamiento, encontramos cambios significativos en algunos parámetros bioquímicos en ambos grupos de tratamiento aunque la mayoría de estos cambios fueron clínicamente irrelevantes. De manera interesante, el porcentaje de usuarias con un índice aterogénico anormal disminuyó de 75\% a 41.6\% luego del periodo de seguimiento.

Conclusiones: El PCA modificó discretamente las variables metabólicas. La mayoría de los cambios fueron no significativos mientras que en las usuarias de ICS fueron más evidentes y hasta quizá benéficos. Los resultados de este intento de evaluar los efectos de los contraceptivos en poblaciones mestiza y americana muestran que los síntomas clínicos son frecuentes en las mujeres mexicanas usuarias de estos métodos. Aunque estos tratamientos pueden afectar algunas variables metabólicas, los cambios parecen clínicamente irrelevantes. La inducción de alteraciones en otras vías fisiopatológicas no se puede descartar.

Palabras clave: Parche cutáneo anticonceptivo, Implante contraceptivo subdérmico, Efectos metabólicos, Cambios metabólicos, Contracepción

\section{Background}

Studying the side effects of contraceptives began with the oral contraceptive pill more than 50 years ago. At the end of the $20^{\text {th }}$ century, oral contraceptives were used by more than 100 million women worldwide [1]. In Mexico, $5.6 \%$ of women use oral contraceptives (1.12 million women in total) [2]. However, after the new contraceptive methods became available, the popularity for oral contraceptives dramatically decreased. Of course, side effects of the oral contraceptives were primarily responsible for the development of new hormonal contraceptive methods. Today, women may choose among several options, including the contraceptive skin patch (CSP) and the subdermal contraceptive implant (SCI).

The CSP was accepted by the U.S. Food and Drug Administration (FDA) in 2001 and was available for clinical use in 2002. The CSP contains $0.6 \mathrm{mg}$ ethinylestradiol (EE) and $6.0 \mathrm{mg}$ norelgestromine (NGMN), although this last dose may change depending on the commercial brand. The CSP mechanism of action is inhibiting the ovulation [3]. The treatment strategy includes changing the CSP every 7 days and then replacing the patch [4]. In each cycle, three different CSP are used. Each SP liberates almost $20 \mu \mathrm{g}$ EE and $150 \mu \mathrm{g}$ NGMN into the blood each day [5]. Therefore, plasma levels ranging from $25-75 \mathrm{pg} / \mathrm{ml} \mathrm{EE}$ and from 0.6-1.2 ng/ml NGMN may be reached [6]. During the fourth week, no patch is used, allowing menstruation [7]. The risk of pregnancy is relatively low (1.24/100 users/year) (95\% CI 0.19-2.33) [8]. Its use is not recommended in women weighing $>90 \mathrm{~kg}$ [4].

On the other hand, the SCI has etonogestrel (ENG) and was approved by the FDA in 2006. Each SCI has ENG (68 mg) the active metabolite of desogestrel (DSG) [9]. ENG inhibits ovulation after reaching a serum level $>90 \mathrm{pg} / \mathrm{ml}$ [10]. The ENG release rate is $40 \mu \mathrm{g} /$ day between days one and five during the menstrual cycle [11]. Eight hours after insertion, serum levels of ENG increase up to a mean of $265 \mathrm{pg} / \mathrm{ml}$, reaching the maximal concentration of the drug $96 \mathrm{~h}$ later [12]. After 1 year of insertion, ENG serum levels decrease to $196 \mathrm{pg} / \mathrm{ml}$ $[12,13]$ and then slowly decline during the next years. The rate of pregnancy is $0.27,0.30$, and $0.38 / 100$ women/year during the first, second and third years, respectively [14].

In Mexico both, the CSP and SCI are now widely used; however, we are unaware about most of the effects of these methods in our population. Therefore, our aim was to evaluate if SP or SCI may induce significant changes in several metabolic pathways in a sample of indigenous and mestizo Mexican women. 


\section{Methods}

\section{Sample selection}

In this observational, prospective, longitudinal, nonrandomized study, Mexican women between 18 and 35 years old were included. Neither researchers nor the physicians assigned the hormonal contraceptive treatment; each woman chose her contraceptive method. Group 1 was composed of users of CSP (6 mg NGM and $0.06 \mathrm{mg}$ $\mathrm{EE}$ ), whereas in Group 2 we included users of SCI (68 mg ENG). We included only one woman belonging to the same family. To be considered as indigenous, women had to belong to one of the several ethnic groups living throughout Mexico and must fulfill all of the following criteria: a) speaking a native language as a first language (with Spanish as a second language); b) living in an indigenous community; c) considering themselves as indigenous; and d) being carriers of blood group $\mathrm{O} R \mathrm{R}(\mathrm{O})$ D-positive [15]. If an interethnic indigenous mixture was demonstrated, the woman continued to be eligible. All categories of mestizo women were included. For all participants, we excluded those with a history of thrombotic events or hemophilia, family history of thrombosis or hemorrhagic diseases, requirement for any type of antithrombotic treatment, renal or liver disease, moderate-tosevere alcoholism or malnutrition, high blood pressure, known atherothrombotic disease, thyroid abnormalities, severe migraine, breast cancer, diabetes mellitus, abnormal uterine bleeding, autoimmune diseases, and current history of smoking. Participants were excluded if they received any contraceptive method during the four months before entering the study or if they were breastfeeding. Finally, we excluded women with more than one hormonal contraceptive method or those who used this kind of medication due to other medical reasons.

The protocol was accepted by the Ethics National Committee of Instituto Mexicano del Seguro Social.

\section{Clinical assessment}

After being enrolled in the study, the following clinical variables were obtained from each woman before and after 4 months of contraceptive use: age, weight, height, abdominal circumference (AC), body mass index (BMI), and systolic (SBP) and diastolic blood pressure (DBP). The study was designed with follow-up period of 4 months because the frequency of side effects among Mexican women users of hormonal contraceptives appears precisely during this period of time.

\section{Sample collection}

Sample collection was made from August 2011 to January 2013. We collected $22 \mathrm{ml}$ of blood from each woman in two vacuum tubes without anticoagulant (Vacutainer, Beckton Dickinson, Rutherford, NJ, USA): one tube with EDTA (Vacutainer), and two tubes with 3.2\% tri-sodium citrate (vol:vol = 1:9) (Vacutainer). Samples were centrifuged immediately after collection at 2,500 $\times$ g for $15 \mathrm{~min}$ and platelet-poor plasma and serum samples were obtained using a disposable Pasteur pipette. All aliquots were prepared using $2 \mathrm{ml}$ Eppendorf tubes and immediately frozen at $-70^{\circ} \mathrm{C}$ until processing. Both, basal samples and samples taken after 4-months of contraceptive treatment were analyzed immediately after collecting the last sample. For quality control tests we used commercially available control sera. With these results, Levey-Jennings graphs were constructed and interpreted in each running test.

\section{Sample size}

Sample size was calculated considering the two most frequent metabolic abnormalities in our population, serum glucose $($ mean $=89 \mathrm{mg} / \mathrm{dl} ; \mathrm{SD}=11.4 \mathrm{mg} / \mathrm{dl})$, and triglycerides (mean 129.8; SD =42.3). As a consequence, an abnormal serum glucose level was considered when $\geq 100 \mathrm{mg} / \mathrm{dl}$ and $\geq 170.1 \mathrm{mg} / \mathrm{dl}$ for triglycerides. For each of these variables we obtained a sample size calculating $\alpha=0.05$ and 1$\beta=0.90$. Therefore, sample sizes were 23 and 24 women according to glucose and triglycerides, respectively. Although $\mathrm{n}=24$ for each study group was sufficient, we enrolled 50 women in each group considering those women not able to finish the study.

\section{Assays}

We performed all assays before initiating the contraceptive method and after 4 months of use by means of commercially available diagnostic kits and using worldwide accepted techniques. We used Synchron LX 20 chemistry analyzer (Beckman Coulter, Fullerton, CA, USA) in order to assay serum levels of glucose, urea, creatinine, uric acid, alkaline phosphatase (AP), lactic dehydrogenase (LDH), serum glutamic pyruvic transaminase (SGPT), serum glutamic oxaloacetic transaminase (SGOT), gamma glutamyl transpeptidase (GGT), total bilirubin (TB), indirect bilirubin (IB), direct bilirubin (DB), total proteins (TP), albumin (Alb), globulins (Glb), triglycerides (TG), total cholesterol (TC), high-density lipoprotein cholesterol (HDL-C), lowdensity lipoprotein cholesterol (LDL-C), and very-lowdensity lipoprotein cholesterol (VLDV-C). Atherogenic index (AI) was calculated as follows: [TC (mg/dl)/HDL-C (mg/dl)]. AXSYM (Abbott Park Laboratories, Abbott Park, IL, USA) was used to evaluate serum levels of thyroidstimulating hormone (TSH), total thyroxine, total triiodothyronine (T3), thyroid uptake, free thyroxine index, serum protein-bound iodine, anti-thyroglobulin antibodies, antithyroid microsomal antibodies as well as high-sensitivity C-reactive protein (hsCRP). With a Synergy HT platelet reader (Biotek Instruments, Winooski, VT, USA), we measured the serum levels of insulin, $C$ peptide, and insulin growth factor-1 (IGF-1). Finally, an ELISA kit was used to 
evaluate leptin [Leptin (Sandwich) ELISA, DRG Diagnostics, Marburg, Germany], and adiponectin levels (Human Adiponectin ELISA kit, Invitrogen, Frederick, MD, USA).

\section{Statistical analysis}

We used the Statistical Package for the Social Sciences (SPSS, v.16; SPSS Inc., Chicago, IL, USA). For the description of demographic characteristics of Mexican women and the results found of the variables analyzed, we used central tendency measures and dispersion. We used Kolmogorov Smirnov test to establish the statistical distribution of each variable. Paired $t$ and Wilcoxon tests were used to analyze basal and post-treatment results. Student $\mathrm{t}$ test or Mann-Whitney $\mathrm{U}$ test was used in order to compare results between groups; $\mathrm{p}$ value $<0.05$ was considered significant.

\section{Ethics}

In this study we required drawing blood, a procedure not routinely performed in users of contraceptives. Therefore, after all women made the decision to receive contraceptive treatment they were informed about the study and signed informed consent was obtained. In order to assure the confidentiality of the information, only the investigators had access to the complete data of the participants. Blinding was broken in case of significant clinical or laboratory abnormalities. The study was carried out according to national and international regulations for clinical research: Ley de General de Salud, the Helsinki Declaration, and the Code of Nuremberg.

\section{Results}

\section{General data}

We included 100 women; however, 38 women did not complete the study because they did not have the second blood sample drawn, the contraceptive method was abandoned, or because they were already pregnant when the contraceptive method was initiated (Figure 1). The main cause for study withdrawal was clinical symptomatology induced by the contraconceptive method itself. Therefore, 62 women completed the study protocol (Figure 1): 25 women were allocated to the CSP group while 37 corresponded to the SCI group. Eighteen women were indigenous and 44 were mestizo. Clinical characteristics of the whole group are shown in Table 1.

Clinical symptoms were relatively frequent during the study period (Figure 1). During the 4-month study period with the CSP, four users had moderate to severe symptomatology: breast pain, skin hypersensitivity, and multiple minor symptomatology. On the other hand, 29 (78\%) women receiving $\mathrm{SCI}$ had at least one moderate to severe clinical symptom. Nineteen of these women had transvaginal hemorrhage followed by amenorrhea in ten of the women (27\%). Abnormal uterine bleeding ranged from minimal and occasional bleeds up to 15-day menstrual periods. Other symptoms related to this contraceptive method are shown in Figure 1. We observed other clinical changes among the enrolled women (Table 1). For example, 13 users of the CSP and 21 of the SCI gained weight: $0.4-9 \mathrm{Kg}$ and $0.4-10 \mathrm{Kg}$, respectively. However, six women (one from the CSP group and five from the $\mathrm{SCI}$ group) lost between 0.5 and $4 \mathrm{Kg}$. BMI and AC also increased, although these changes were not significant. No significant changes in SBP or DBP were observed. None of the women who completed the study became pregnant.

\section{Basal tests}

For both groups no significant renal, liver, or thyroid abnormalities were identified. None of the women had diabetes but five (9.2\%) had a serum glucose $>100 \mathrm{mg} / \mathrm{dl}$. Almost $30 \%$ of the women had a TG level $>166 \mathrm{mg} / \mathrm{dl}$; $66 \%$ had HDL-C $<45 \mathrm{mg} / \mathrm{dl}$; and the AI was $>4.0$ in $57.4 \%$ of the participants (Tables 2 and 3). Levels of insulin, $C$ peptide, IFG-1, adiponectin, and leptin were always normal (Tables 4 and 5). AP $(\mathrm{p}=0.040)$ and $\mathrm{LDH}$ $(\mathrm{p}=0.035)$ were higher in women in the SCI treatment group. There were no other significant differences between the study groups.

\section{Metabolic effects of contraceptive hormonal therapy}

After the 4-month follow-up period, the pattern of metabolic changes induced by SCI in indigenous and mestizo women was quite similar. For example, glucose levels decreased 90.2-82.5 mg/dl $(\mathrm{p}=0.002)$ in indigenous women and $89.6-84.1 \mathrm{mg} / \mathrm{dl}(\mathrm{p}=0.002)$ in mestizo women. TB and IB also significantly decreased only in indigenous women $(\mathrm{p}=0.003$ and $\mathrm{p}=0.002$, respectively). On the contrary, DB levels significantly increased $0.08-0.10 \mathrm{mg} / \mathrm{dl}(\mathrm{p}=0.046)$ in indigenous and 0.09$0.12 \mathrm{mg} / \mathrm{dl}(\mathrm{p}=0.007)$ in mestizo women. Although no modification in the lipid profile was observed in indigenous, in mestizo women there was a significant decrease in the levels of TG $(148-100 \mathrm{mg} / \mathrm{dl}, \mathrm{p}=0.030)$, TC (163$139 \mathrm{mg} / \mathrm{dl}, \mathrm{p}=0.010)$, LDL-C (104-82 mg/dl, $\mathrm{p}=0.035)$, and VLDL-C $(29-20 \mathrm{mg} / \mathrm{dl}, \mathrm{p}=0.050)$ after the end of the study period. AI was lower in both groups after treatment, 3.9-3.3 ( $\mathrm{p}=0.009)$ for indigenous and 4.8-3.7 $(\mathrm{p}<0.001)$ for mestizo women. Levels of SGOT and SGPT significantly decreased after the hormonal therapy period only in indigenous women: 29.1-23.0 IU/l ( $p=$ $0.004)$ and 28.3-21.9 IU/l ( $\mathrm{p}=0.047)$, respectively. A significant elevation in LDH (151.6-168.6 UI/l, $\mathrm{p}=0.013)$, GGT (19.6-23.8 IU/l, p=0.035), PT (6.9-7.3 g/dl, $\mathrm{p}=$ $0.029)$, and Alb (3.9-4.4 g/dl, p=0.001) levels were observed only in mestizo women. Finally, in indigenous women we found a significant elevation in peptide $C$ 


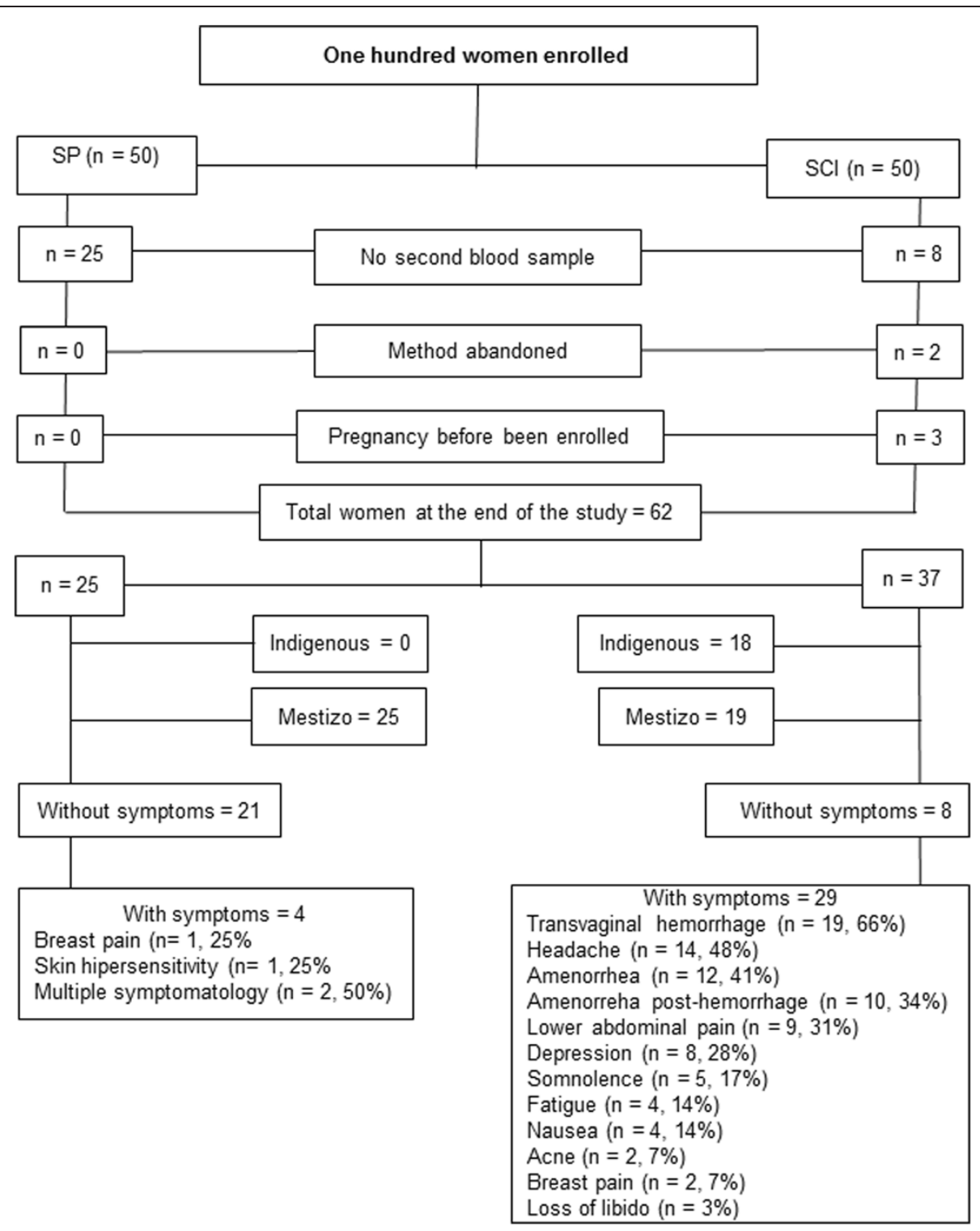

Figure 1 Complete study design.

Table 1 Demographics of users of hormonal contraceptive treatment $(n=62)$

\begin{tabular}{|c|c|c|c|c|c|c|}
\hline \multirow[b]{2}{*}{ Variable } & \multicolumn{2}{|c|}{$\operatorname{CSP}(n=25)$} & \multirow[b]{2}{*}{$\mathbf{p}$} & \multicolumn{2}{|c|}{$\mathrm{SCl}(\mathrm{n}=37)$} & \multirow[b]{2}{*}{ p } \\
\hline & Basal & 4 months & & Basal & 4 months & \\
\hline Age (years) & $23.9(18-32)^{*}$ & $23.9(18-32)$ & NA & $28.0(18-35)^{*}$ & $28.0(18-35)$ & NA \\
\hline Weight (kg) & $59.3(42-90)$ & $60.9(47-88)$ & 0.058 & $57.5(36-91)$ & $60.0(39-101)$ & 0.056 \\
\hline Height (m) & $1.6(1.5-1.7)$ & $1.6(1.5-1.7)$ & NA & $1.52(1.38-1.64)$ & $1.52(1.38-1.64)$ & NA \\
\hline $\mathrm{BMI}\left(\mathrm{kg} / \mathrm{m}^{2}\right)$ & $24.6(19.2-39)$ & $25.3(21.5-38.1)$ & 0.062 & $24.7(16.0-38.5)$ & $25.8(17.3-39.9)$ & 0.062 \\
\hline $\mathrm{AC}(\mathrm{cm})$ & $79(62-110)$ & 80.5 (64.0-109) & 0.057 & $82(58-101)$ & 85.1 (60-109) & 0.053 \\
\hline $\mathrm{SBP}(\mathrm{mmHg})$ & 108 (90-120) & $107(100-120)$ & 0.588 & $107(90-120)$ & 107 (90-120) & 0.980 \\
\hline $\mathrm{DBP}(\mathrm{mmHg})$ & $71(60-80)$ & $70(60-80)$ & 0.695 & $68(60-80)$ & $69(68-80)$ & 0.678 \\
\hline
\end{tabular}

Results are presented as mean (ranges). AC, abdominal circumference; BMI, body mass index; SBP, systolic blood pressure; DBP, diastolic blood pressure. ${ }^{*} \mathrm{p}<0.050$ between basal contraceptive skin patch (CSP) vs. basal subdermal contraceptive implant (SCI). 
Table 2 Metabolic variables before and after 4 months with SCI

\begin{tabular}{|c|c|c|c|c|}
\hline Variable & Basal & 4 months & $\mathbf{p}$ & Reference values \\
\hline Glucose $[\mathrm{mg} / \mathrm{dl}]$ & $91.3(80.7-116.6)$ & $85.4(66.0-100.2)$ & 0.034 & $65-114$ \\
\hline Urea [mg/dl] & $21.8(14.4-29.0)$ & $20.7(12.8-28.8)$ & 0.405 & $15-39$ \\
\hline Creatinine [mg/dl] & $0.59(0.4-0.7)$ & $0.60(0.5-0.8)$ & 0.179 & $0.5-1.2$ \\
\hline Uric acid [mg/dl] & $4.5(2.7-6.1)$ & $4.2(3.0-6.3)$ & 0.418 & $2.6-7.2$ \\
\hline $\mathrm{TG}[\mathrm{mg} / \mathrm{dl}]$ & $136.9(64.5-244.7)$ & $104.1(34.7-220.3)$ & 0.002 & $54-214$ \\
\hline $\mathrm{TC}[\mathrm{mg} / \mathrm{dl}]$ & $163.7(118.2-214.1)$ & $144.6(93.0-206.2)$ & 0.001 & $140-220$ \\
\hline $\mathrm{HDL}-\mathrm{C}[\mathrm{mg} / \mathrm{dl}]$ & $38.2(20.6-60.8)$ & $38.7(25.0-58.4)$ & 0.751 & $21-75$ \\
\hline $\mathrm{LDL}-\mathrm{C}[\mathrm{mg} / \mathrm{dl}]$ & $98.0(66.2-145.8)$ & $84.7(48.4-124.2)$ & 0.012 & $56-155$ \\
\hline VLDL-C [mg/dl] & $27.3(12.9-48.9)$ & $20.8(6.9-44.1)$ & 0.025 & \\
\hline $\mathrm{Al}$ & $4.54(2.7-6.4)$ & $3.83(2.2-5.3)$ & 0.002 & $<4$ \\
\hline $\mathrm{TB}[\mathrm{mg} / \mathrm{dl}]$ & $0.63(0.2-1.2)$ & $0.56(0.3-1.0)$ & 0.121 & $0.2-1.0$ \\
\hline $\mathrm{DB}[\mathrm{mg} / \mathrm{dl}]$ & $0.08(0.0-0.1)$ & $0.11(0.1-0.2)$ & 0.050 & $0.0-0.2$ \\
\hline $\mathrm{IB}[\mathrm{mg} / \mathrm{dl}]$ & $0.55(0.2-1.1)$ & $0.45(0.2-0.8)$ & 0.025 & \\
\hline SGOT [U/I] & $25.2(15.1-48.0)$ & $22.3(13.2-32.0)$ & 0.167 & $15-37$ \\
\hline SGPT [U/I] & $24.9(10.0-59.3)$ & $21.5(8.7-39.5)$ & 0.081 & $8-35$ \\
\hline $\mathrm{AP}[\mathrm{U} / \mathrm{I}]$ & $80.2(58.2-144.9)$ & $75.8(48.7-121.7)$ & 0.093 & $37-110$ \\
\hline LDH [U/I] & $144(110.8-190.0)$ & $154.5(115.6-195.9)$ & 0.005 & $106-274$ \\
\hline GGT [U/l] & $21.7(5.7-68.6)$ & $26.9(7.0-76.4)$ & 0.009 & $5-24$ \\
\hline $\mathrm{TP}[\mathrm{g} / \mathrm{dl}]$ & $7.0(6.3-7.6)$ & $7.2(6.8-7.8)$ & 0.121 & $6.7-8.2$ \\
\hline Alb [g/dl] & $4.1(3.7-4.6)$ & $4.3(3.9-4.8)$ & 0.132 & $3.8-5.1$ \\
\hline $\mathrm{Glb}[\mathrm{g} / \mathrm{dl}]$ & $2.84(2.3-3.1)$ & $2.83(2.4-3.3)$ & 0.747 & \\
\hline
\end{tabular}

Results are expressed as medians (percentiles: 2.5-97.5). Reference values (RV) for metabolic variables are showed in the fifth column. Significant $p$ values are shown in bold. Glucose $(p=0.012)$, triglycerides (TG; $p<0.001)$, total cholesterol (TC; $p<0.001)$, serum glutamic oxaloacetic transaminase (SGOT; $p=0.002)$, serum glutamic pyruvic transaminase (SGPT; $p<0.001)$, alkaline phosphatase (AP; $p=0.001)$, total bilirubin (TB; $p=0.027)$, indirect bilirubin (IB; $p=0.008)$, albumin (Alb; $p=0.027)$, globulins (Glb; $p=0.020)$, very-low-density lipoprotein cholesterol (VLDL-C; $p<0.001)$, gammaglutamyl transferase (GGT; $p<0.001)$, and high sensitivity $\mathrm{C}$-reactive protein (hsCRP; $\mathrm{p}=0.002$ ), had an abnormal distribution. $\mathrm{SCl}$ : subdermal contraceptive implant; TG: triglycerides; HDL-C: high-density lipoprotein cholesterol; LDL-C: low-density lipoprotein cholesterol; Al: atherogenic index; DB: direct bilirubin; LDH: lactate dehydrogenase; and TP: total proteins. Kolmogorov Smirnov test was used to establishing the distribution of variables. Mann-Whitney $\mathrm{U}$ test and Wilcoxon test were used in order to analyze non-parametric values. Student $\mathrm{t}$ test and paired t tests were used for parametric variables.

levels $(2.7-3.9 \mathrm{ng} / \mathrm{ml}, \mathrm{p}=0.002)$, whereas a significant decrease in terms of insulin levels was found in mestizo women $(15.0-10.4 \mu \mathrm{U} / \mathrm{ml}, \mathrm{p}=0.027)$. The only thyroid test significantly modified was TSH concentration, which decreased from 2.4-2.0 $\mu \mathrm{U} / \mathrm{mL}(\mathrm{p}=0.035)$ in mestizo women. No significant changes were observed in the concentrations of adiponectin and leptin before and after treatment with CSP or SCI.

Because no one of the indigenous women used a CSP and due to the results observed for indigenous and mestizo women in the SCI group were similar, we performed the subsequent analysis of the results considering the women enrolled in the SCI group as a whole. Results for all variables analyzed are shown in Tables 23,4 and 5 . We found few significant changes in liver, renal, or thyroid tests. In some SCI users, we observed a decrease in the serum concentrations of glucose, TG, TC, LDL-C, and VLDL-C (Table 2). The percentage of users with an abnormal AI diminished from $75 \%$ at the beginning of the study to $41.6 \%$ after completing the follow-up. Liver function tests demonstrated a partial decrease in IB levels but an increase of 10 and $5 \mathrm{U} / \mathrm{dl}$ for $\mathrm{LDH}$ and GGT, respectively (Table 2). Also, we noticed an increase in IGF-1 levels (Table 4).

In the CSP group we observed a slight but significant decrease in TB, IB, AP, and TU levels as well as an increase in $\mathrm{T}_{3}$ (Tables 3 and 5). Also, we found an increase in hsCRP levels (Table 5).

\section{Discussion}

Today it is well known that CSP has a similar tolerability and rate of effects as oral contraceptives [16]. For example, the CSP increases TC, HDL-C, TG, and decreases LDL-C [17]. The CSP also induce non-adverse effects on the carbohydrate metabolism and liver function tests [17]. Furthermore, it has been proven that the CSP may induce changes in the blood coagulation system [18,19]. Other common adverse effects include skin reactions at the site of application, breast discomfort during the first two cycles, and dysmenorrhea [20]. Nausea, emotional lability, 
Table 3 Metabolic variables before and after 4 months with the CSP

\begin{tabular}{|c|c|c|c|c|}
\hline Variable (RV) & Basal & 4 months & $p$ & Reference values \\
\hline Glucose [mg/dl] & $89.5(73.0-110.0)$ & $92.2(80.0-104.0)$ & 0.289 & $65-114$ \\
\hline Urea [mg/dl] & $19.2(8.6-35.1)$ & $20.4(12.8-28.8)$ & 0.362 & $15-39$ \\
\hline Creatinine $[\mathrm{mg} / \mathrm{dl}]$ & $0.55(0.4-0.8)$ & $0.59(0.5-0.8)$ & 0.071 & $0.5-1.2$ \\
\hline Uric acid [mg/dl] & $4.3(2.8-6.5)$ & $4.1(3.1-6.1)$ & 0.299 & $2.6-7.2$ \\
\hline $\mathrm{TG}[\mathrm{mg} / \mathrm{dl}]$ & $132.3(50.7-307.0)$ & 149.7 (82.3-224.8) & 0.174 & $54-214$ \\
\hline $\mathrm{TC}[\mathrm{mg} / \mathrm{dl}]$ & $171.9(142.1-222.3)$ & $179.7(137.8-235.7)$ & 0.201 & $140-220$ \\
\hline $\mathrm{HDL}-\mathrm{C}[\mathrm{mg} / \mathrm{dl}]$ & $41.8(22.5-64.1)$ & $44.4(22.9-67.1)$ & 0.220 & $21-75$ \\
\hline LDL-C [mg/dl] & 104.7 (58.9-143.5) & 105.4 (73.1-152.1) & 0.906 & $56-155$ \\
\hline VLDL-C [mg/dl] & $26.3(10.1-62.0)$ & $29.9(16.5-45.0)$ & 0.192 & \\
\hline $\mathrm{Al}$ & $4.41(2.9-8.4)$ & $4.33(2.9-7.6)$ & 0.613 & $<4$ \\
\hline $\mathrm{TB}[\mathrm{mg} / \mathrm{dl}]$ & $0.64(0.2-1.2)$ & $0.51(0.2-0.9)$ & 0.048 & $0.2-1.0$ \\
\hline $\mathrm{DB}[\mathrm{mg} / \mathrm{dl}]$ & $0.09(0.0-0.2)$ & $0.09(0.0-0.2)$ & 0.797 & $0.0-0.2$ \\
\hline $\mathrm{IB}[\mathrm{mg} / \mathrm{dl}]$ & $0.55(0.1-1.0)$ & $0.42(0.1-0.9)$ & 0.032 & \\
\hline SGOT [U/I] & $22.4(15.6-37.5)$ & $22.5(15.0-46.3)$ & 0.974 & $15-37$ \\
\hline SGPT [U/l] & $19.6(8.0-46.8)$ & $17.6(9.6-38.8)$ & 0.321 & $8-35$ \\
\hline $\mathrm{AP}[\mathrm{U} / \mathrm{l}]$ & $68.0(42.7-98.8)^{*}$ & $60.4(40.5-86.9)$ & 0.025 & $37-110$ \\
\hline LDH [U/l] & $129.8(80.6-166.8)^{*}$ & $120.8(86.0-162.5)$ & 0.053 & $106-274$ \\
\hline GGT [U/l] & $18.4(9.6-31.9)$ & $17.1(5.6-34.5)$ & 0.259 & $5-24$ \\
\hline $\operatorname{TP}[\mathrm{g} / \mathrm{dl}]$ & $7.0(5.9-8.6)$ & $6.9(6.0-8.0)$ & 0.431 & $6.7-8.2$ \\
\hline Alb [g/dl] & $4.1(3.4-4.9)$ & $3.9(3.3-4.6)$ & 0.061 & $3.8-5.1$ \\
\hline $\mathrm{Glb}[\mathrm{g} / \mathrm{dl}]$ & $2.94(2.3-3.8)$ & $2.98(2.5-3.5)$ & 0.721 & \\
\hline
\end{tabular}

Results are expressed as median (percentiles: 2.5-97.5). Reference values (RV) are showed in the fifth column. Significant $\mathrm{p}$ values are shown in bold. Creatinine $(p<0.012)$, triglycerides (TG; $p=0.002)$, serum glutamic oxaloacetic transaminase (SGOT; $p<0.001)$, serum glutamic pyruvic transaminase (SGPT; $p<0.001)$, very-low-density lipoprotein cholesterol (VLDL-C; $p=0.002$ ) and high sensitivity C-reactive protein (hsCRP; $p<0.001$ ), had an abnormal distribution. CSP: contraceptive skin patch; TC: total cholesterol; HDL-C: high-density lipoprotein cholesterol; LDL-C: low-density lipoprotein cholesterol; Al: atherogenic index; DB: direct bilirubin; IB: indirect bilirubin; TB: total bilirubin; GGT: gammaglutamyl transferase; AP: alkaline phosphatase; LDH: lactate dehydrogenase; TP: total proteins; Alb: albumin; Glb: globulins. Kolmogorov Smirnov test was used to establishing the distribution of variables. Mann-Whitney $U$ test and Wilcoxon test were used in order to analyze non-parametric values. Student $\mathrm{t}$ test and paired $\mathrm{t}$ tests were used for parametric variables.

headache, and occasional breakthrough bleeding are less frequently reported [21,22]. Effects of the SCI on most metabolic variables and on the blood coagulation system do not seem relevant [23-27]. Headache and dyspnea are frequent complaints [28], and a low rate of anxiety/ depression (1-9\%) has been reported [28]. Nausea, breast tenderness, lower abdominal pain, loss of libido, and fatigue are infrequent symptoms [28]. Weight gain has not consistently been associated with either CSP or SCI.

One hundred Mexican women were screened prior to entering a contraception program. In the CSP group, women were students, professionals, and housewives, whereas in the SCI group all users were homemakers. Despite these differences, the clinical characteristics were homogeneous between groups except for age because users of the CSP were younger.

Almost 30\% of women were excluded from this study. Most were enrolled in the CSP group. We do not have a clear explanation for this finding. Perhaps the younger age of women in this group or the ease for withdrawal from the method determined this fact. A relatively low number of women were screened at the end of the 4month study period in the CSP group. In the SCI group we were able to complete the study with $80 \%$ of the women originally enrolled. In this last group, only one user required withdrawal of the device 2 months after starting the study due to severe hemorrhage. After the 4-month study period, $30 \%$ of women in the SCI group had secondary effects.

Regarding laboratory abnormalities, the CSP slightly modified the metabolic variables analyzed but most of these changes were not clinically significant. Among the SCI users, changes were more evident but in some cases could be considered as beneficial. We observed a decrease in glucose concentration, a fact without a clear explanation. We may hypothesize that the increase of IGF-1 may be responsible for this phenomenon as previously suggested [29]. Indeed, in type 2 diabetic patients, IGF-1 glucose levels and insulin requirements are lower [30]. Moreover, in nondiabetic patients, IGF-1 increases insulin sensitivity and glucose metabolism while suppressing lipolysis and postprandial lipemia [31]. Although the increase in serum 
Table 4 Thyroid screening, leptin, adiponectin, insulin, C peptide, IGF-1, and hsCRP before and after 4 months with SCI

\begin{tabular}{|c|c|c|c|c|}
\hline Variable & Basal & 4 months & $p$ & Reference values \\
\hline $\mathrm{TSH}(\mu \mathrm{U} / \mathrm{ml})$ & $2.0(0.4-5.7)$ & $1.6(0.4-5.5)$ & 0.034 & $0.34-5.60$ \\
\hline $\mathrm{T}_{4}(\mu \mathrm{g} / \mathrm{dl})$ & $8.1(4.2-11.7)$ & $8.6(6.3-12.7)$ & 0.120 & $6.09-12.23$ \\
\hline $\mathrm{T}_{3}(\mathrm{ng} / \mathrm{dl})$ & $120.6(79.2-208.4)$ & $123.1(92.6-173.4)$ & 0.622 & $75.0-250.0$ \\
\hline FTI & $7.8(3.9-12.1)$ & $8.3(6.1-13.4)$ & 0.367 & $4.5-15.0$ \\
\hline $\mathrm{PBI}(\mu \mathrm{g} / \mathrm{dl})$ & $5.2(2.7-7.6)$ & $5.6(4.1-8.2)$ & 0.117 & $3.90-7.80$ \\
\hline TU (\%) & $0.9(0.9-1.0)$ & $0.9(0.8-1.0)$ & 0.974 & $0.75-1.25$ \\
\hline Anti-Tg $(\mu \mathrm{U} / \mathrm{ml})$ & $15.8(5.0-103.4)$ & $14.2(5.0-86.2)$ & 0.625 & $5-100$ \\
\hline Anti-TPO $(\mu \mathrm{U} / \mathrm{ml})$ & $1.5(0.3-59.0)$ & $1.4(0.3-43.0)$ & 0.052 & $0-9$ \\
\hline Insulin $(\mu \mathrm{U} / \mathrm{ml})$ & $13.0(4.5-43.1)$ & $11.2(3.7-26.8)$ & 0.449 & $5-30$ \\
\hline C peptide $(\mathrm{ng} / \mathrm{ml})$ & $3.1(1.3-7.4)$ & $3.4(1.8-5.8)$ & 0.128 & $0.5-3.0$ \\
\hline IGF-1 C (pg/ml) & $251.2(76.5-486.4)$ & $279.7(119.1-593.5)$ & 0.016 & $115.0-307$ \\
\hline Leptin (ng/ml) & $9.1(1.5-50.3)$ & $11.1(1.0-32.8)$ & 0.812 & $4.1-22.4$ \\
\hline Adiponectin $(\mu \mathrm{g} / \mathrm{ml})$ & $16.0(8.9-29.9)$ & $14.7(9.0-26.2)$ & 0.837 & $3.9-25.6$ \\
\hline $\mathrm{hsCRP}(\mathrm{mg} / \mathrm{dl})$ & $0.26(0.02-1.2)$ & $0.25(0.03-1.0)$ & 0.837 & $0.0-0.8$ \\
\hline
\end{tabular}

Results are expressed as median (percentiles: 2.5-97.5). Significant $\mathrm{p}$ values are shown in bold. All variables had an abnormal distribution ( $\mathrm{p}<0.050)$. TSH: thyroid-stimulating hormone; T4: total thyroxine; T3: total triiodothyronine; FTI: free thyroxine index; PBI: serum protein-bound iodine; TU: thyroid uptake; anti-Tg: anti-thyroglobulin antibodies; anti-TPO: anti-thyroid microsomal antibodies; IGF-1: insulin growth factor-1; hsCRP: high-sensitivity C-reactive protein. Kolmogorov Smirnov test was used to establishing the distribution of variables. Mann-Whitney $U$ test and Wilcoxon test were used in order to analyze non-parametric values. Student $\mathrm{t}$ test and paired $\mathrm{t}$ tests were used for parametric variables.

levels of IGF-1 may partially explain the changes in glucose metabolism, we must underline that this phenomenon does not appear to be a risk factor for contraceptive users.

On the other hand, the AI decreased and, of course, this is a finding that may suggest a positive relationship between the risk of atherothrombotic disease and the use of SCI. As described for the CSP, we also observed a significant decrease of IB. Previous studies evaluating the effects of SCI reported an increase of IB, hemoglobin, and hematocrit due to either the presence of amenorrhea or to the low frequency of hemorrhage [32-34]. In this study amenorrhea was infrequently observed but hemorrhage was a predominant symptom, a fact that may explain the decrease of IB levels. According to the thyroid and liver

Table 5 Thyroid screening, leptin, adiponectin, insulin, C peptide, IGF-1, and hsCRP before and after 4 months with the CSP

\begin{tabular}{|c|c|c|c|c|}
\hline Variable & Basal & 4 months & $p$ & Reference values \\
\hline $\mathrm{TSH}(\mu \mathrm{U} / \mathrm{ml})$ & $2.4(0.8-6.2)$ & $1.9(0.7-3.9)$ & 0.158 & $0.34-5.60$ \\
\hline $\mathrm{T}_{4}(\mu \mathrm{g} / \mathrm{dl})$ & $8.5(6.1-11.5)$ & $9.2(7.0-11.4)$ & 0.072 & $6.09-12.23$ \\
\hline $\mathrm{T}_{3}(\mathrm{ng} / \mathrm{dl})$ & $124.2(68.1-188.3)$ & $148.2(110.0-220.2)$ & 0.001 & $75-250$ \\
\hline FTI & $8.2(5.7-11.9)$ & $8.3(6.9-10.0)$ & 0.864 & $4.5-15.0$ \\
\hline $\mathrm{PBI}(\mu \mathrm{g} / \mathrm{dl})$ & $5.5(4.0-7.5)$ & $6.0(4.6-7.4)$ & 0.070 & $3.90-7.80$ \\
\hline TU (\%) & $1.0(0.8-1.2)$ & $0.8(0.8-1.0)$ & 0.009 & $0.75-1.25$ \\
\hline Anti-Tg $(\mu \mathrm{U} / \mathrm{ml})$ & $8.1(5.0-333.1)$ & $7.1(5.1-230.4)$ & 0.159 & $5-100$ \\
\hline Anti-TPO $(\mu \mathrm{U} / \mathrm{ml})$ & $0.7(0.3-404.7)$ & $0.7(0.3-378.3)$ & 0.915 & $0-9$ \\
\hline Insulin $(\mu \mathrm{U} / \mathrm{ml})$ & $8.7(3.8-33.2)$ & $9.2(4.7-19.5)$ & 0.547 & $5-30$ \\
\hline C peptide (ng/ml) & $2.7(1.6-5.7)$ & $2.8(1.8-4.2)$ & 0.559 & $0.5-3.0$ \\
\hline IGF-1 C (pg/ml) & $227.0(89.3-499.0)$ & $225.4(16.9-369.3)$ & 0.775 & 115-307 \\
\hline Leptin (ng/ml) & $9.5(1.9-24.2)$ & $8.9(3.8-30.0)$ & 0.090 & $4.1-22.4$ \\
\hline Adiponectin $(\mu \mathrm{g} / \mathrm{ml})$ & $16.6(6.5-41.8)$ & $17.9(5.2-32.1)$ & 0.409 & $3.9-25.6$ \\
\hline $\mathrm{hsCRP}(\mathrm{mg} / \mathrm{dl})$ & $0.28(0.01-1.0)$ & $0.51(0.1-1.3)$ & 0.013 & $0.0-0.8$ \\
\hline
\end{tabular}

Results are expressed as median (percentiles: $2.5-97.5)$. Significant $p$ values are shown in bold. With the exception of total thyroxine (T4; $p=0.373$ ), thyroid uptake (TU; $p=0.748$ ) and serum protein-bound iodine ( $\mathrm{PBI} ; \mathrm{p}=0.594)$, all variables had an abnormal distribution $(\mathrm{p}<0.050)$. TSH: thyroid-stimulating hormone; T3: total triiodothyronine; FTI: free thyroxine index; anti-Tg: anti-thyroglobulin antibodies; anti-TPO: anti-thyroid microsomal antibodies; IGF-1: insulin growth factor-1; hsCRP: high-sensitivity C-reactive protein (hsCRP). Kolmogorov Smirnov test was used to establishing the distribution of variables. Mann-Whitney $U$ test and Wilcoxon test were used to analyze non-parametric values. Student $t$ test and paired $t$ tests were used for parametric variables. 
function tests, we observed minimal changes, only being significant for LDH, GGT, and TSH. These changes cannot be considered as adverse effects because the levels were always within normal ranges. Fortunately, this pattern of non-adverse effects remains similar when the SCI is used for longer periods of time [35].

Leptin and adiponectin, two cytokines that regulate metabolism, have gained attention in recent years due to their relation with other pathophysiological states. Low levels of adiponectin are associated with obesity, insulin resistance, and type 2 diabetes mellitus [36] as well as atherosclerosis, high blood pressure and coronary artery disease [37]. Moreover, a low adiponectin level is a strong risk factor for the development of metabolic syndrome [38]. On the other hand, leptin levels are not only associated with the amount of fat accumulated but also the energy balance of an individual. Abnormal leptin levels significantly influence the metabolic and hormonal processes in the organism [39]. High plasma levels of this cytokine are associated with obesity, insulin resistance, and glucose intolerance. These last two entities are strongly associated with the development of diabetes [40]. On these bases, we considered important to evaluate these cytokines before and after the treatment. However, we did not find significant changes in either CSI or CSP users. Adiponectin levels remained almost unchanged, whereas leptin showed minimal changes, especially in CSP users.

In order to determine if the metabolic changes may be related to the presence of an inflammatory state, we assayed the hsCRP, a very sensitive acute phase reactant for these purposes [41,42]. After 4 months, levels of this protein significantly rose only in the CSP group, up to almost 50\% compared to basal levels. These data differ from previous reports in which hsCRP rose $220 \%$ after 2 months of SP use [18], a fact that suggests that the CSP may be associated with an important pro-inflammatory state only during the beginning of contraceptive therapy.

Due to the high mestizage of our population, we attempted to present a representative sample of Mexican women and to determine their overall metabolic response to contraceptive therapy. Although with modern techniques it is possible to establish the genetic background of an individual, it is accepted that sociocultural criteria and the presence of blood group $O$ have sensitivity and specificity levels high enough to consider an individual as indigenous [15]. On the contrary, to identify a mestizo woman is quite simple after analyzing the phenotype of the individual and after interrogation about the origin of the user. To our knowledge, this is the first attempt to evaluate the metabolic effects of contraceptives in native-American populations. Eighteen indigenous women who were treated with SCI completed the study and the analysis of the metabolic changes induced by this contraceptive method showed that they had only slight differences as compared with mestizo women. Unfortunately, this analysis was not possible for the CSP group because none indigenous woman choose the CSP. Therefore, our results strongly suggest that at least the SCI does not induces clinical or biochemical relevant changes in either indigenous or mestizo Mexican women.

Of course, this study has some limitations. First, the non-randomized design of the research may be considered a major pitfall and a source of biased results however, considering that all around the world women chose the contraceptive method they desire to use, it was impossible to perform this study with a randomized design. Second, we are aware of our small sample a fact that may have some impact on the conclusions of the study. However, it must be stated that most of the literature addressing the secondary effects of contraceptive treatments include similar numbers of patients.

\section{Conclusion}

Our results show that clinical symptoms are frequent in Mexican users of the CSP and SCI and that the symptomatology is sometimes clinically important. The increase in weight in half of the women was the predominant clinical symptom in users of both, CSP and SCI while abnormal uterine bleeding was highly frequent in users of SCI. Also, our study demonstrates that although estrogens or progestins may affect the overall metabolism of the users, these changes seem clinically irrelevant. It should be underlined that we followed the users only during a 4-month period, a fact that obligates us to exercise caution about the possible impact of these contraceptive methods for longer or perhaps shorter periods. Finally, it should be considered that we analyzed some metabolic patterns before and after the contraception therapy but induction of abnormalities affecting other physiological pathways cannot be ruled out.

\section{Abbreviations}

CSP: Contraceptive skin patch; FDA: Food and drug administration; EE: Ethinylestradiol; NGMN: Norelgestromine; SCl: Subdermal contraceptive implant; ENG: Etonogestrel; DSG: Desogestrel; AC: Abdominal circumference; BMI: Body mass index; SBP: Systolic blood pressure; DBP: Diastolic blood pressure; AP: Alkaline phosphatase; LDH: Lactic dehydrogenase; SGPT: Serum glutamic pyruvic transaminase; SGOT: Serum glutamic oxaloacetic transaminase; GGT: Gamma glutamyl transpeptidase; TB: Total bilirubin; IB: Indirect bilirubin; DB: Direct bilirubin; TP: Total proteins; Alb: Albumin; Glb: Globulins; TG: Triglycerides; TC: Total cholesterol; HDL-C: High-density lipoprotein cholesterol; LDL-C: Low-density lipoprotein cholesterol; VLDL-C: Very-low-density lipoprotein cholesterol; TSH: Thyroid-stimulating hormone; T3: Total triiodothyronine; hsCRP: High-sensitivity C-reactive protein; IGF-1: Insulin growth factor-1; Al: Atherogenic index; T4: Total thyroxine; FTI: Free thyroxine index; PBI: Serum protein-bound iodine; TU: Thyroid uptake; anti-Tg: Anti-thyroglobulin antibodies; anti-TPO: Anti-thyroid microsomal antibodies.

\section{Competing interests}

The authors declare that they have no competing interests. 


\section{Authors' contributions}

$\mathrm{HJ}$ : design, acquisition of data, analysis of blood samples and interpretation of data, drafting of the manuscript, final approval of the version to be published. EAGL: design, drafting the manuscript, final approval of the version to be published. MMH: acquisition of blood samples and clinical data, analysis of blood samples and interpretation of data, and drafting the manuscript, final approval of the version to be published. JFMP: first approach to the patients, acquisition of blood samples and clinical data, final approval of the version to be published. MARE: acquisition of clinical data analysis and interpretation of data. GCH: acquisition of clinical data, analysis and interpretation of data. RJN: design, acquisition of clinical data, analysis and interpretation of clinical data, revising of the manuscript regarding intellectual content, final approval of the version to be published. XHG: first approach to the patients, acquisition of blood samples and clinical data, analysis and interpretation of data. RP-G: first approach to the patients, acquisition of blood samples and clinical data, analysis of data. II-S: analysis and interpretation of clinical data, revising of the manuscript regarding intellectual content, final approval of the version to be published. AM-C design, analysis and interpretation of data, drafting of the manuscript, final approval of the version to be published. All authors read and approved the final manuscript.

\section{Acknowledgment}

This research was done with a grant from the Consejo Nacional de Ciencia y Tecnología (CONACyT) (SALUD-2008-C01-87138). JH-J received a grant during the period between August 2010 and June 2012 from the Instituto Politecnico Nacional. AM-C is a receipt of a grant from Fundación IMSS.

\section{Author details}

'Unidad de Investigacion Medica en Trombosis Hemostasia y Aterogenesis, Instituto Mexicano del Seguro Social, Mexico City, Mexico. ${ }^{2}$ Escuela Nacional de Ciencias Biológicas, Instituto Politécnico Nacional, Mexico, D.F, Mexico. ${ }^{3}$ Centro de Salud Urbano Tehuacan, JS No. 10, SSA, Tehuacan, Puebla, Mexico. ${ }^{4}$ UMF 9, Instituto Mexicano del Seguro Social, Tehuacan, Puebla, Mexico. ${ }^{5}$ UMF 30, Instituto Mexicano del Seguro Social, Tehuacan, Puebla, Mexico.

Received: 19 October 2013 Accepted: 9 April 2014

Published: 26 April 2014

\section{References}

1. World Health Organization: Cardiovascular Disease and Steroid Hormone Contraception. Report of a WHO Scientific group. World Health Organ Tech Rep Ser 1998, 877:1-89.

2. Instituto Nacional de Estadística, Geografía e Informática. Mexico: Estadísticas generales. http://dgcnesyp.inegi.gob.mx

3. Dittrich R, Parker L, Rosen JB, Shangold G, Creasy GW, Fisher AC, Ortho Evra/ Evra 001 Study Group: Transdermal contraception: evaluation of three transdermal norelgestromin/ethinyl estradiol doses in a randomized, multicentre, dose-response study. Am J Obstet Gynecol 2002, 186:15-20.

4. Janssen-Cilag International NV: Evra transdermal patch. Summary of product characteristics. http://www.janssen-cilag.co.uk/product/pdf/spc/ 00121.pdf

5. Abrams LS, Skee D, Natarajan J, Wong FA: Pharmacokinetic overview of Ortho EvraTM/EvraTM. Fertil Steril 2002, 77(Suppl 1):S3-S12.

6. Abrams LS, Skee DM, Wong FA, Anderson NJ, Leese PT: Pharmacokinetics of norelgestromin and ethinyl estradiol from two consecutive contraceptive patches. J Clin Pharmacol 2001, 41:1232-1237.

7. Abrams LS, Skee D, Natarajan J, Wong FA, Anderson GD: Pharmacokinetics of a contraceptive patch (EvraTM/Ortho EvraTM) containing norelgestromin and ethinyloestradiol at four application sites. J Clin Pharmacol 2001, 53:141-146.

8. Audet MC, Moreau M, Koltun WD, Waldbaum AS, Shangold G, Fisher AC, Creasy GW, ORTHO, EVRA/EVRA 004 Study Group: Evaluation of contraceptive efficacy and cycle control of a transdermal contraceptive patch vs. an oral contraceptive. JAMA 2001, 285:2347-2355.

9. Croxatto HB: Mechanisms that explain the contraceptive action of progestin implants for women. Contraception 2002, 65:21-27.

10. Diaz S, Pavez M, Moo-Young AJ, Bardin CW, Croxatto HB: Clinical trial with 3-keto-desogestrel subdermal implants. Contraception 1991, 44:393-408.
11. Davies GC, Feng LX, Newton JR, Van Beek A, Coelingh-Bennink HJ: Release characteristics, ovarian activity and menstrual bleeding pattern with a single contraceptive implant releasing 3-ketodesogestrel. Contraception 1993, 47:251-261.

12. Makarainen $L$, van Beek $A$, Tuomivaara $L$, Asplund B, Coelingh Bennink $H$ : Ovarian function during the use of a single contraceptive implant: Implanon compared with Norplant. Fertil Steril 1998, 69:714-721.

13. Croxatto HB, Makarainen $L$ : The pharmacodynamics and efficacy of Implanon. An overview of the data. Contraception 1998, 58(Suppl 2):91S-97S.

14. Darney P, Patel A, Rosen K, Shapiro LS, Kaunitz AM: Safety and efficacy of a single-rod etonogestrel implant (Implanon): results from 11 international clinical trials. Fertil Steril 2009, 91:1646-1653.

15. Lisker R, Ramírez E, Babinsky V: Genetic structure of autochtonous populations of Meso-America: Mexico. Human Biol 1996, 68:395-404.

16. Radowicki S, Skórzewska K, Szlendak K: Safety evaluation of a transdermal contraceptive system with an oral contraceptive. Ginekol Pol 2005, 76:884-889.

17. Kiriwat O, Petyim S: The effects of transdermal contraception on lipid profiles, carbohydrate metabolism and coagulogram in Thai women. Gynecol Endocrinol 2010, 26:361-365.

18. Johnson JV, Lowell J, Badger GJ, Rosing J, Tchaikovski S, Cushman M: Effects of oral and transdermal hormonal contraception on vascular risk markers: a randomized controlled trial. Obstet Gynecol 2008, 11:278-284.

19. Fleischer K, van Vliet HA, Rosendaal FR, Rosing J, Tchaikovski S, Helmerhorst FM: Effects of the contraceptive patch, the vaginal ring and an oral contraceptive on APC resistance and SHBG: a cross-over study. Thromb Res 2009, 123:429-435.

20. Sibai BM, Odlind V, Meador ML, Shangold GA, Fisher AC, Creasy GW: A comparative and pooled analysis of the safety and tolerability of the contraceptive patch (Ortho Evra/Evra). Fertil Steril 2002, 77(Suppl 1):S19-S26.

21. Smallwood GH, Meador ML, Lenihan JP, Shangold GA, Fisher AC, Creasy W: ORTHO EVRA/EVRA 002 Study Group: Efficacy and safety of a transdermal contraceptive system. Obstet Gynecol 2001, 98:799-805.

22. Harel Z, Riggs S, Vaz R, Flanagan P, Dunn K, Harel D: Adolescents' experience with the combined estrogen and progestin transdermal contraceptive method Ortho Evra. J Pediatr Adolesc Gynecol 2005, 18:85-90.

23. Vieira CS, Ferriani RA, Garcia AA, Gomes MK, Azevedo GD, de Sá MF S: Transitory reduction of platelet aggregation with the use of etonogestrel implant in healthy women. Thromb Haemost 2005, 94:682-683.

24. Egberg N, van Beek A, Gunnervik C, Hulkko S, Hirvonen E, Larsson-Cohn U, Bennink HC: Effects on the hemostatic system and liver function in relation to Implanon and Norplant. A prospective randomized clinical trial. Contraception 1998, 58:93-98.

25. Biswas A, Viegas OA, Roy AC: Effect of Implanon and Norplant subderma contraceptive implants on serum lipids-a randomized comparative study. Contraception 2003, 68:189-193.

26. Merki-Feld GS, Imthurn B, Seifert B: Effects of the progestagen-only contraceptive implant Implanon on cardiovascular risk factors. Clin Endocrinol (Oxf) 2008, 68:355-360.

27. Biswas A, Biswas S, Viegas OA: Effect of etonogestrel subdermal contraceptive implant (Implanon) on liver function tests-a randomized comparative study with Norplant implants. Contraception 2004, 70:379-382

28. Brache V, Faundes A, Alvarez F, Cochon L: Non-menstrual adverse events during use of implantable contraceptives for women: data from clinical trials. Contraception 2002, 65:63-74.

29. Rinderknecht $E$, Humbel RE: The amino acid sequence of human insulinlike growth factor I and its structural homology with proinsulin. J Biol Chem 1978, 253:2769-2776.

30. Clemmons DR, Moses AC, McKay MJ, Sommer A, Rosen DM, Ruckle J: The combination of insulin-like growth factor I and insulin-like growth factor binding protein-3 reduces insulin requirements in insulin-dependent type 1 diabetes: evidence for in vivo biological activity. J Clin Endocrinol Metab 2000, 85:1518-1524

31. Paolisso G, Tagliamonte MR, Rizzo MR, Giugliano D: Advancing age and insulin resistance: new facts about an ancient history. Eur J Clin Invest 1999, 29:758-769.

32. Guazzelli CA, de Queiroz FT, Barbieri M, Torloni MR, de Araujo FF: Etonogestrel implant in postpartum adolescents: bleeding pattern, efficacy and discontinuation rate. Contraception 2010, 82:256-259. 
33. World Health Organization: Effects of contraceptives on hemoglobin and ferritin. Task Force for Epidemiological Research on Reproductive Health, United Nations Development Programme/United Nations Population Fund/World Health Organization/World Bank Special Programme of Research, Development and Research Training in Human Reproduction. Contraception 1998, 58:262-273.

34. Guazzelli CA, de Queiroz FT, Barbieri M, Barreiros FA, Torloni MR, Araujo FF: Metabolic effects of contraceptive implants in adolescents. Contraception 2011, 84:409-412.

35. Inal MM, Yildirim Y, Ertopcu K, Avci ME, Ozelmas I, Tinar S: Effect of the subdermal contraceptive Etonogestrel implant (Implanon) on biochemical and hormonal parameters (three years follow-up). Eur I Contracept Reprod Health Care 2008, 13:238-242.

36. Arita Y, Kihara S, Ouchi N, Takahashi M, Maeda K, Miyagawa J, Hotta K, Shimomura I, Nakamura T, Miyaoka K, Kuriyama H, Nishida M, Yamashita S, Okubo K, Matsubara K, Muraguchi M, Ohmoto Y, Funahashi T, Matsuzawa Y: Paradoxical decrease of an adipose-specific protein, adiponectin, in obesity. Biochem Biophys Res Commun 1999, 257:79-83.

37. Han SH, Sakuma I, Shin EK, Koh KK: Antiatherosclerotic and anti-insulin resistance effects of adiponectin: basic and clinical studies. Prog Cardiovasc Dis 2009, 52:126-140.

38. Hung J, McQuillan BM, Thompson PL, Beilby JP: Circulating adiponectin levels associate with inflammatory markers, insulin resistance and metabolic syndrome independent of obesity. Int J Obes 2008, 32:772-779.

39. Kelesidis T, Kelesidis I, Chou S, Mantzoros CS: Narrative review: The role of leptin in human physiology: emerging clinical applications. Ann Intern Med 2010, 152:93-100

40. Sun Q, van Dam RM, Meigs JB, Franco OH, Mantzoros CS, Hu FB: Leptin and soluble leptin receptor levels in plasma and risk of type 2 diabetes in U.S. women: a prospective study. Diabetes 2010, 59:611-618.

41. Ridker PM: Clinical application of C-reactive protein for cardiovascular disease detection and prevention. Circulation 2003, 107:363-369.

42. Libby P: Inflammation in atherosclerosis. Nature 2002, 420:868-874.

\section{doi:10.1186/1742-4755-11-33}

Cite this article as: Hernandez-Juarez et al: Metabolic effects of the contraceptive skin patch and subdermal contraceptive implant in Mexican women: A prospective study. Reproductive Health 2014 11:33.

\section{Submit your next manuscript to BioMed Central and take full advantage of:}

- Convenient online submission

- Thorough peer review

- No space constraints or color figure charges

- Immediate publication on acceptance

- Inclusion in PubMed, CAS, Scopus and Google Scholar

- Research which is freely available for redistribution 